\title{
Thermal and Structural Analysis of Blade using Radial Cooling Holes
}

\author{
Pradnya Rajaram Bhondiwale \\ M.E. Student Department of Mechanical Engineering \\ Manjara Charitable Trust, \\ Rajiv Gandhi Institute of Technology, Mumbai \\ Juhu-Versova Link Road, Versova, Andheri (w)
}

\author{
Nitin K. Deshmukh \\ Assistant Professor of Mechanical Engineering \\ Manjara Charitable Trust, \\ Rajiv Gandhi Institute of Technology, Mumbai \\ Juhu-Versova Link Road, Versova, Andheri (w)
}

\begin{abstract}
Gas turbines are used for a/c propulsion and industrial applications. The thermal efficiency improved by increasing turbine inlet temperatures. The cooling systems are required for continuous safe operation of gas turbines. Different methods have been suggested for the cooling of the blade and one such technique is to have radial holes to pass high velocity cooling air along the span.

The turbine blade designed with no holes, six holes and eight holes. The heat transfer analysis is done in CFD software FLUENT (a turbulence reliable k-e model with enhanced wall treatment.) The present used material for blade is Inconel 625, N-155 and Hoste alloy, while comparing these results, Hoste alloy has proved to have better thermal properties and also induces stresses are less than Inconel 625 and N-155.
\end{abstract}

Keywords-CFD software fluent, Thermal and Structural analysis, blade materials like Inconel 625, N-155 and Hoste alloy etc.

\section{INTRODUCTION TO TURBINE BLADE}

A turbine blade is the individual component which makes up the turbine section of a gas turbine. The blades are responsible for extracting energy from the high temperature, high pressure gas produced by the combustor. The turbine blades are often the limiting component of gas turbines. To survive in this difficult environment, turbine blades often use exotic materials like super-alloys and many different methods of cooling, such as internal air channels, boundary layer cooling, and thermal barrier coatings.

\section{A. BLADE MATERIALS}

1. Inconel 625:- Material properties are Young's modulus $150000 \mathrm{MPa}$, Poisson's ratio 0.31, Density $8400 \mathrm{Kg} / \mathrm{m}^{3}$, Thermal conductivity $10 \mathrm{~W} / \mathrm{m} . \mathrm{K}$

2. N 155:- Young's modulus $143000 \mathrm{MPa}$, Poisson's ratio 0.33 , Density $8249 \mathrm{Kg} / \mathrm{m}^{3}$, Thermal conductivity $20 \mathrm{~W} / \mathrm{m} . \mathrm{K}$

3. Hoste alloy :- Material properties are Young's modulus $144000 \mathrm{MPa}$, Poisson's ratio 0.348, Density $8300 \mathrm{Kg} / \mathrm{m}^{3}$, Thermal conductivity 20 $\mathrm{W} / \mathrm{m} . \mathrm{K}$

\section{B. METHODS OF COOLING}

Components of the gas turbine blade are cooled by air or liquid cooling. For air cooling the less quantity of air required such as $1.5-3 \%$ of main flow and blade temperature can be reduced by $250-300^{\circ} \mathrm{C}$.there are many types of cooling used in gas turbine blades.

1. Internal cooling

- Convection cooling

- Impingement cooling

2. External cooling

- Film cooling

- Cooling effusion

- Pin fin cooling

\section{LITERATURE SURVEY}

Theju $\mathbf{V}$ et.al.[1]- the aim of the project is to design and analyze blade.an investigation for the usage of new materials is required. in present work, turbine blade was designed with two different materials (Inconel 718 \&Titanium T-6)

K. HariBrahmaiah et.al.[2]- Structural \&Thermal analysis done for two different material(Chromium steel \& Inconel 718) in ANSYS Software. the better material for the blade analyzed.invastigation is carried out for blade without holes and with no of holes like 5,9 and13 holes.

V. Veeraragavan et.al.[3]- in this project work by using FEA the prediction of the location of possible temperature areas on turbine blade will be done and examine suitable material for the blade of gas turbine engine..

Shridhar Paregouda et.al.[4]- in this work the predictions Reynolds-Averaged Navier-Stokes solution for a baseline Flat film cooling geometry will be the analyzed and compared with experimental data.analysis is carried with software like CFD and FEA. Three film-cooling holes with different hole geometries including a standard cylindrical hole and two holes with a diffuser shaped exit portion (i.e. a fanshaped and a laidback fanshaped hole) will be studied.

\section{Types of analysis-}

\section{METHODOLOGY}

- Structural analysis consists of linear and nonlinear models. Linear models use simple parameters and assume that the material is not plastically deformed. 
- Vibrational analysis is used to test a material against random vibrations, shock, and impact. Each of these incidences may act on the natural vibrational frequency of the material which, in turn, may cause resonance and subsequent failure.

- Heat Transfer analysis models the conductivity or thermal fluid dynamics of the material or structure.

2. Basic steps to perform CFD analysis-

I) Preprocessing-

A. 3D Models of Blade

1. Blade without hole

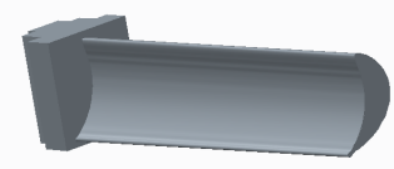

Fig.1 without hole

2. Blade with six holes

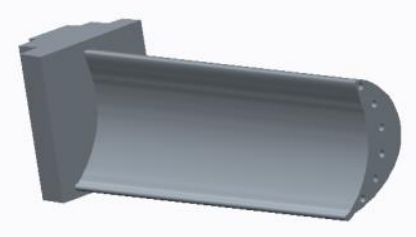

Fig. 2 with six holes

3. Blade with eight holes

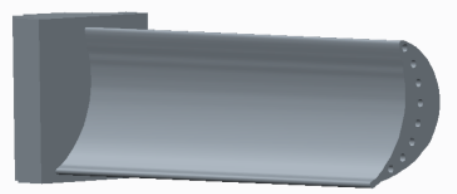

Fig.3 with eight holes

B. Meshing-
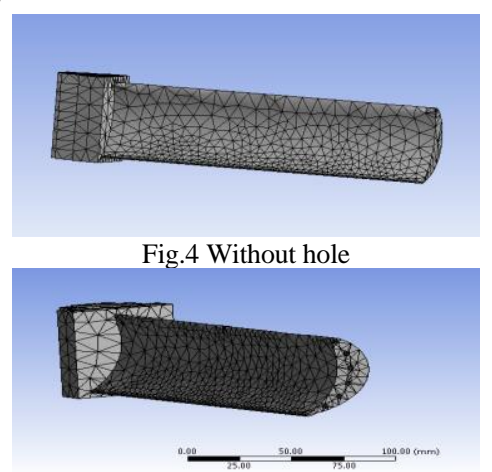

Fig.5 With six holes

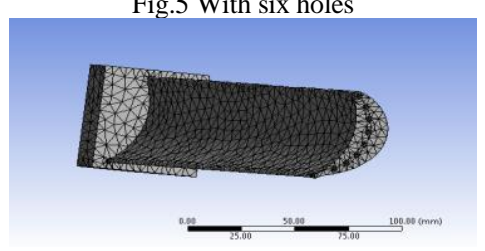

Fig.6 With eight holes

\section{II) Solution-}

The dataset prepared by the preprocessor is used as input to the finite element

Code itself, which constructs and solves a system of linear or nonlinear algebraic equations are

$$
\mathrm{K}_{\mathrm{ij}} \mathrm{u}_{\mathrm{j}}=\mathrm{f}_{\mathrm{i}}
$$

Where $\mathrm{u}$ and $\mathrm{f}$ are the displacements and externally applied force at the nodal points. The formation of the $\mathrm{K}$ matrix is dependent on the type of problem being attacked, and this module will outline the approach for truss and linear elastic stress analyses. Commercial codes may have very large element libraries, with elements appropriate to a wide range of problem types. One of FEA's principal advantages is that many problem types can be addressed with the same code, merely by specifying the appropriate element types from the library.

\section{III) Post processing-}

This process used for viewing and interpretation of result. The results can be viewed in various animations, graph etc.

\section{RESULT ANALYSIS}

A. Structural Analysis of Blade with 8 holes hoste alloy

\section{Deformation}

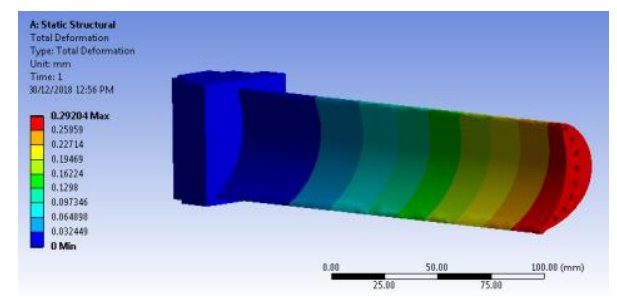

Fig.7 Deformation in blade with eight holes hoste alloy

\section{Strain}

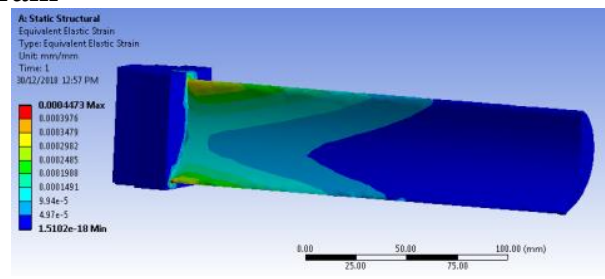

Fig.8 Strain in blade with eight holes hoste alloy

3. Stress

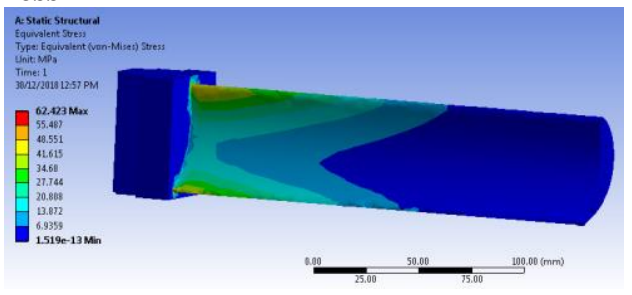

Fig.9 Stress in blade with eight holes hoste alloy

B. Thermal Analysis with 8 holes hoste alloy 1. Temperature 


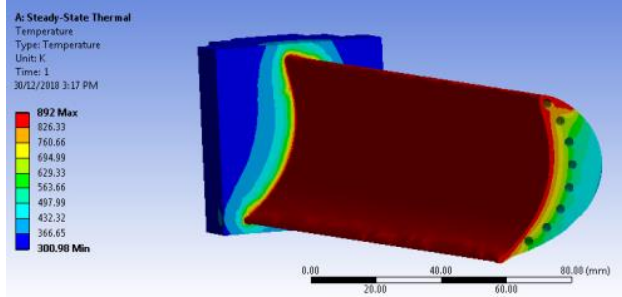

Fig.10 Temperature distribution profile

\section{Heat Flux}

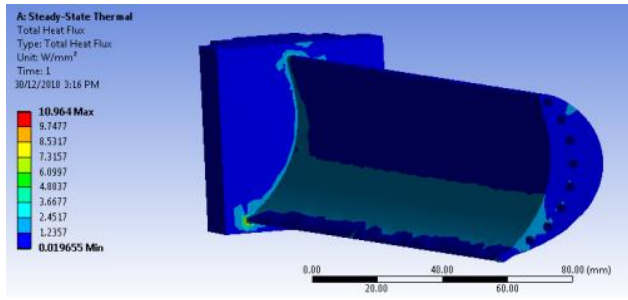

Fig.11 Heat Flux distribution profile

C. Final Results Table

1. CFD Analysis

\begin{tabular}{|l|l|l|l|l|}
\hline & $\begin{array}{l}\text { Pressure } \\
(P a)\end{array}$ & $\begin{array}{l}\text { Velocity } \\
(\mathrm{m} / \mathrm{s})\end{array}$ & $\begin{array}{l}\text { Temperature } \\
(\mathrm{K})\end{array}$ & $\begin{array}{l}\text { Heat } \\
\text { transfer } \\
\text { coefficient } \\
\left(\mathrm{W} / \mathrm{m}^{2} \mathrm{~K}\right)\end{array}$ \\
\hline $\begin{array}{l}\text { Without } \\
\text { holes }\end{array}$ & $6.61 \mathrm{e}+04$ & $9.16 \mathrm{e}+02$ & $8.92 \mathrm{e}+02$ & $1.90 \mathrm{e}+03$ \\
\hline $\begin{array}{l}\text { With 6 } \\
\text { holes }\end{array}$ & $6.52 \mathrm{e}+04$ & $9.22 \mathrm{e}+02$ & $8.92 \mathrm{e}+02$ & $1.88 \mathrm{e}+03$ \\
\hline $\begin{array}{l}\text { With 8 } \\
\text { holes }\end{array}$ & $6.36 \mathrm{e}+04$ & $9.39 \mathrm{e}+02$ & $8.92 \mathrm{e}+02$ & $1.82 \mathrm{e}+03$ \\
\hline
\end{tabular}

2. Structural Analysis

\begin{tabular}{|c|c|c|c|}
\hline & \multicolumn{3}{|c|}{ Deformation (mm) } \\
\cline { 2 - 4 } & $\mathrm{N}-155$ & $\begin{array}{c}\text { Hoste } \\
\text { alloy }\end{array}$ & $\begin{array}{c}\text { Inconel } \\
625\end{array}$ \\
\hline $\begin{array}{c}\text { Without } \\
\text { holes }\end{array}$ & $\begin{array}{c}0.268 \\
11\end{array}$ & $\mathbf{0 . 2 6 6 0 9}$ & $\mathbf{0 . 2 5 6 3 6}$ \\
\hline $\begin{array}{c}\text { With 6 } \\
\text { holes }\end{array}$ & $\begin{array}{c}\mathbf{0 . 2 9 0} \\
95\end{array}$ & $\mathbf{0 . 2 8 8 8 3}$ & $\mathbf{0 . 2 7 8 3 6}$ \\
\hline $\begin{array}{c}\text { With 8 } \\
\text { holes }\end{array}$ & $\begin{array}{c}\mathbf{0 . 2 9 4} \\
18\end{array}$ & $\mathbf{0 . 2 9 2 0 4}$ & $\mathbf{0 . 2 8 1 4 4}$ \\
\hline
\end{tabular}

Table 2: Deformation Results

\begin{tabular}{|c|c|c|c|}
\hline & \multicolumn{3}{|c|}{ Strain } \\
\cline { 2 - 4 } & N-155 & $\begin{array}{c}\text { Hoste } \\
\text { allov }\end{array}$ & $\begin{array}{c}\text { Inconel } \\
625\end{array}$ \\
\hline $\begin{array}{c}\text { Without } \\
\text { holes }\end{array}$ & $\begin{array}{c}\mathbf{0 . 0 0 0 3} \\
\mathbf{3 7 9 8}\end{array}$ & $\begin{array}{c}\mathbf{0 . 0 0 0 3} \\
\mathbf{3 4 4 2}\end{array}$ & $\begin{array}{c}\mathbf{0 . 0 0 0 3 3} \\
\mathbf{0 6 4}\end{array}$ \\
\hline With 6 & $\mathbf{0 . 0 0 0 3}$ & $\mathbf{0 . 0 0 0 3}$ & $\mathbf{0 . 0 0 0 3 7}$ \\
\hline Won & $\mathbf{0 7 0 0}$ & $\mathbf{0 0 0}$ \\
With 8 & $\mathbf{0 . 0 0 0 4}$ & $\mathbf{0 . 0 0 0 4}$ & $\mathbf{0 . 0 0 0 4 2}$ \\
holes & $\mathbf{5 0 1}$ & $\mathbf{4 7 3}$ & $\mathbf{6 6 7}$ \\
\hline
\end{tabular}

Table 3: Strain Results

\begin{tabular}{|l|l|l|l|}
\hline \multirow{2}{*}{} & \multicolumn{3}{|c|}{$\begin{array}{l}\text { Stress } \\
\text { (MPa) }\end{array}$} \\
\cline { 2 - 4 } & $\mathrm{N}-155$ & $\begin{array}{l}\text { Hoste } \\
\text { alloy }\end{array}$ & Inconel 625 \\
\hline Without holes & 48.048 & 47.873 & 49.341 \\
\hline With 6 holes & 55.029 & 54.956 & 55.673 \\
\hline With 8 holes & 62.356 & 62.423 & 61.831 \\
\hline
\end{tabular}

Table 4: Stress Results

\section{Thermal Analysis}

\begin{tabular}{|l|l|l|l|l|l|l|}
\hline & \multicolumn{2}{|l|}{ Temperature min $(\mathrm{k})$} & \multicolumn{2}{l|}{ Heat Flux $\left(\mathrm{W} / \mathrm{mm}^{2}\right)$} \\
\cline { 2 - 7 } & $\mathrm{N}-155$ & $\begin{array}{l}\text { Hoste } \\
\text { alloy }\end{array}$ & $\begin{array}{l}\text { Inconel } \\
625\end{array}$ & $\mathrm{~N}-155$ & $\begin{array}{l}\text { Hoste } \\
\text { alloy }\end{array}$ & $\begin{array}{l}\text { Inconel } \\
625\end{array}$ \\
\hline $\begin{array}{l}\text { Without } \\
\text { holes }\end{array}$ & 299.63 & 302.53 & 295.92 & 2.1303 & 2.5255 & 1.4554 \\
\hline $\begin{array}{l}\text { With 6 } \\
\text { holes }\end{array}$ & 298.95 & 301.48 & 293.79 & 2.2145 & 2.6491 & 4.1881 \\
\hline $\begin{array}{l}\text { With 8 } \\
\text { holes }\end{array}$ & 298.6 & 300.98 & 279.68 & 9.1879 & 10.964 & 5.2543 \\
\hline
\end{tabular}

Table 2: Thermal Analysis

\section{Comparison Analysis Graphs}

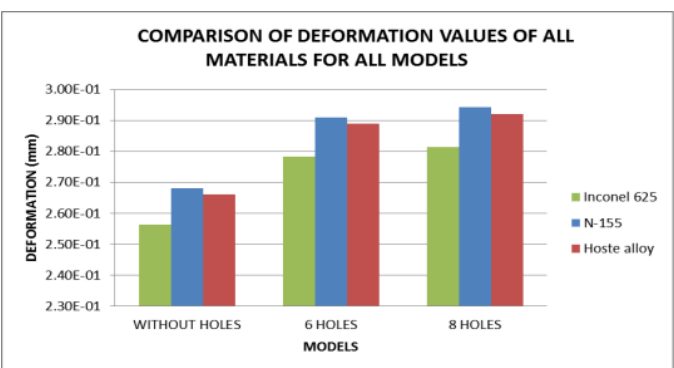

Fig.12 Graph for deformation vs models

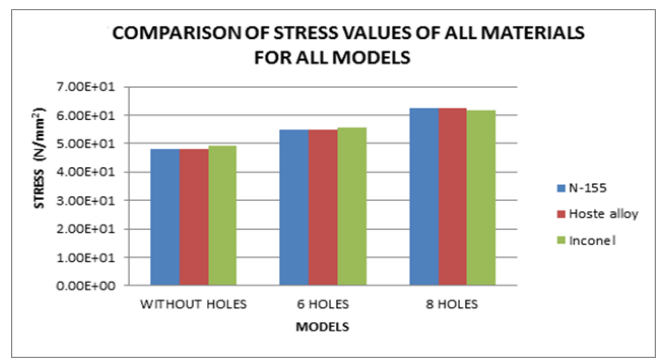

Fig.12 Graph for stress vs models

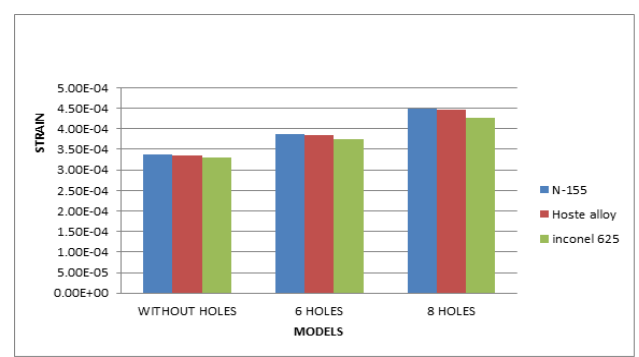

Fig.12 Graph for strain vs models

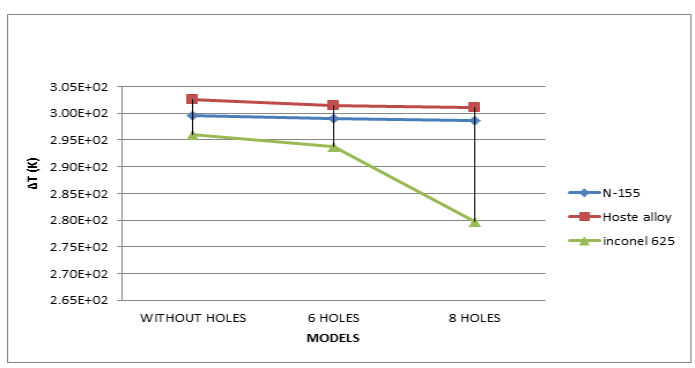

Fig.13 Graph for temperature difference vs models 


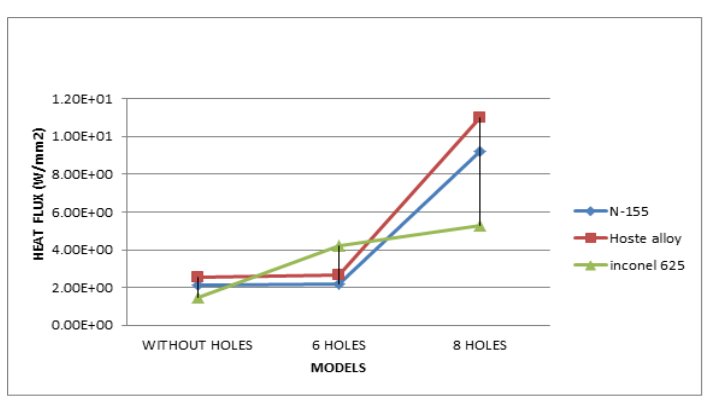

Fig.12 Graph for heat flux vs models

\section{CONCLUSION}

The turbine blade is designed with no holes, 6 holes and 8 holes for blade cooling purpose with materials like N-155, Inconel 625, Hoste alloy respectively. By observing the structural analysis results, the stresses are increasing with increase of number of holes. By comparing the results, they are less for material Inconel 625. The stress values for all materials are less than the respective yield stress values. So using all the 3 materials is safe under given load conditions. Similarly by observing the thermal analysis results, the heat transfer rate is increasing by increasing the no. of holes and it is more for Hoste alloy. So from the above two analysis it can be concluded that providing 8 holes for Hoste alloy is better.

\section{REFERENCES:}

[1] Theju V, Uday P S , PLV Gopinath Reddy, C.J.Manjunath, Design and Analysis of Gas Turbine Blade, International Journal of Innovative Research in Science, Engineering and Technology, Vol. 3, Issue 6, June 2014

[2] K. HariBrahmaiah, M. Lava Kumar, Heat Transfer Analysis of Gas Turbine Blade Through Cooling Holes, ISSN (e): $2250-$ 3005 || Vol, 04 || Issue, 7 || July - 2014 ||International Journal of Computational Engineering Research (IJCER)

[3] V.Veeraragavan, Effect Of Temperature Distribution In 10c4/60c50 Gas Turbine Blade Model Using Finite Element Analysis, International Journal of Engineering Research \& Technology, Vol.1 - Issue 10 (December - 2012), e-ISSN: 22780181

[4] K. Takeishi, S. Aoki, T. Sato and K. Tsukagoshi, Film Cooling on a Gas Turbine Rotor Blade, J. Turbomach 114(4), 828-834 (Oct 01, 1992) (7 pages), doi:10.1115/1.2928036

[5] M. Y. Jabbari, K. C. Marston, E. R. G. Eckert and R. J. Goldstein, Film Cooling of the Gas Turbine Endwall, J. Turbomach 118(2), 278-284 (Apr 01, 1996) (7 pages), doi:10.1115/1.2836637

[6] A. Immarigeon, Discrete-Hole Injection by An advanced impingement/film cooling scheme for gas turbines - numerical study, International Journal of Numerical Methods for Heat \& Fluid Flow, Vol. 16 No. 4, 2006, pp. 470-493 